Supplement of Earth Syst. Dynam., 8, 1237-1246, 2017

https://doi.org/10.5194/esd-8-1237-2017-supplement

(c) Author(s) 2017. This work is distributed under

the Creative Commons Attribution 3.0 License.

(c) (i)

Supplement of

\title{
Synergy between land use and climate change increases future fire risk in Amazon forests
}

Yannick Le Page et al.

Correspondence to: Yannick Le Page (niquya@gmail.com)

The copyright of individual parts of the supplement might differ from the CC BY 3.0 License. 


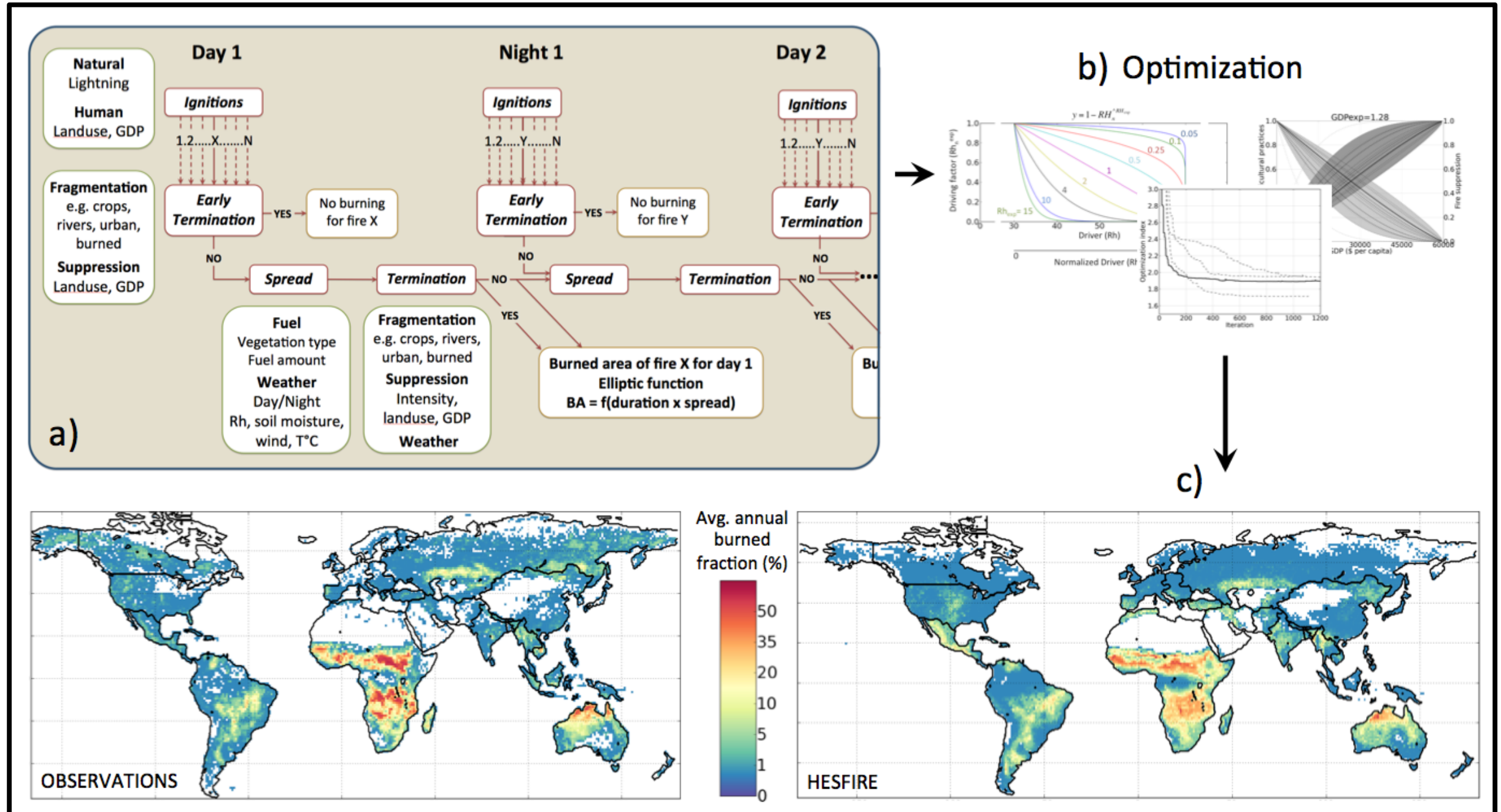

Figure S 1. The HESFIRE model (Le Page et al., 2015). a) model diagram; b) optimization procedure; c) evaluation of performances with satellite-derived observation data (GFEDv3, (van der Werf et al., 2010)). 


\section{Model outputs with original, global scale parameterization}

Annual burned area 1999-2010

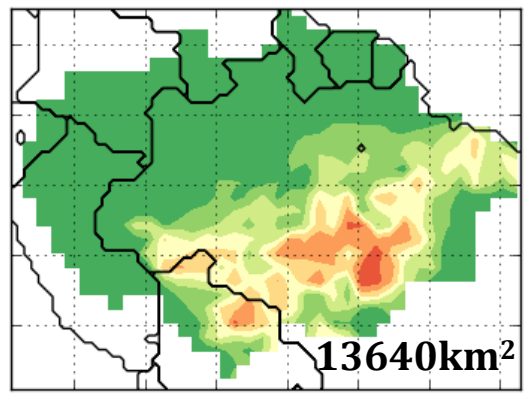

$0 \begin{array}{llllll}0.05 .1 .25 & .5 & 1 & 2 & 4 & 8\end{array}$

Average annual burned fraction (forest fires only)
Interannual variability $\left(10^{3} \mathrm{~km}^{2}\right)$

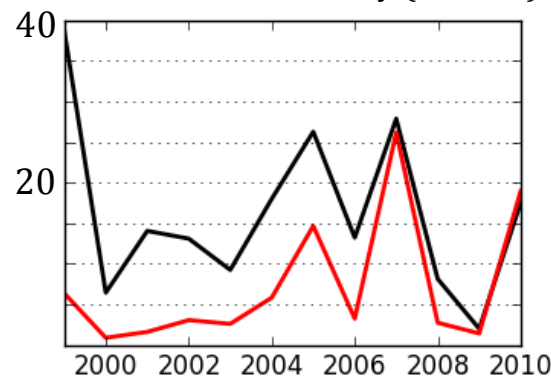

- Model

Observations
Fire size distribution (\%)

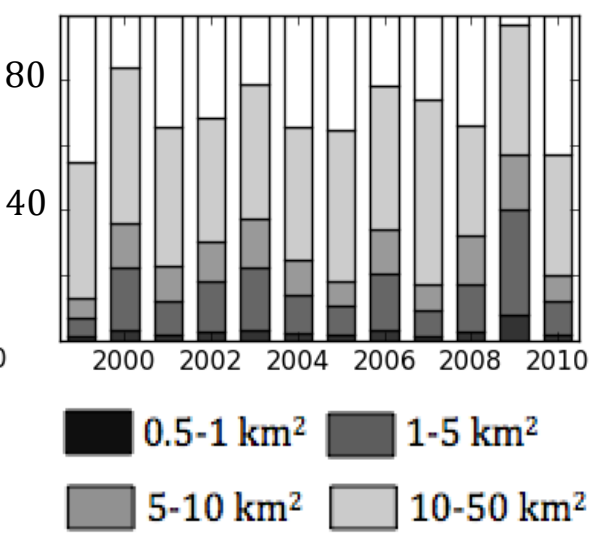

$>50 \mathrm{~km}^{2}$

Figure S2. Spatial and temporal patterns of modeled understory fires in the Amazon as modeled with the original HESFIRE parameterization (Le Page et al., 2015). 


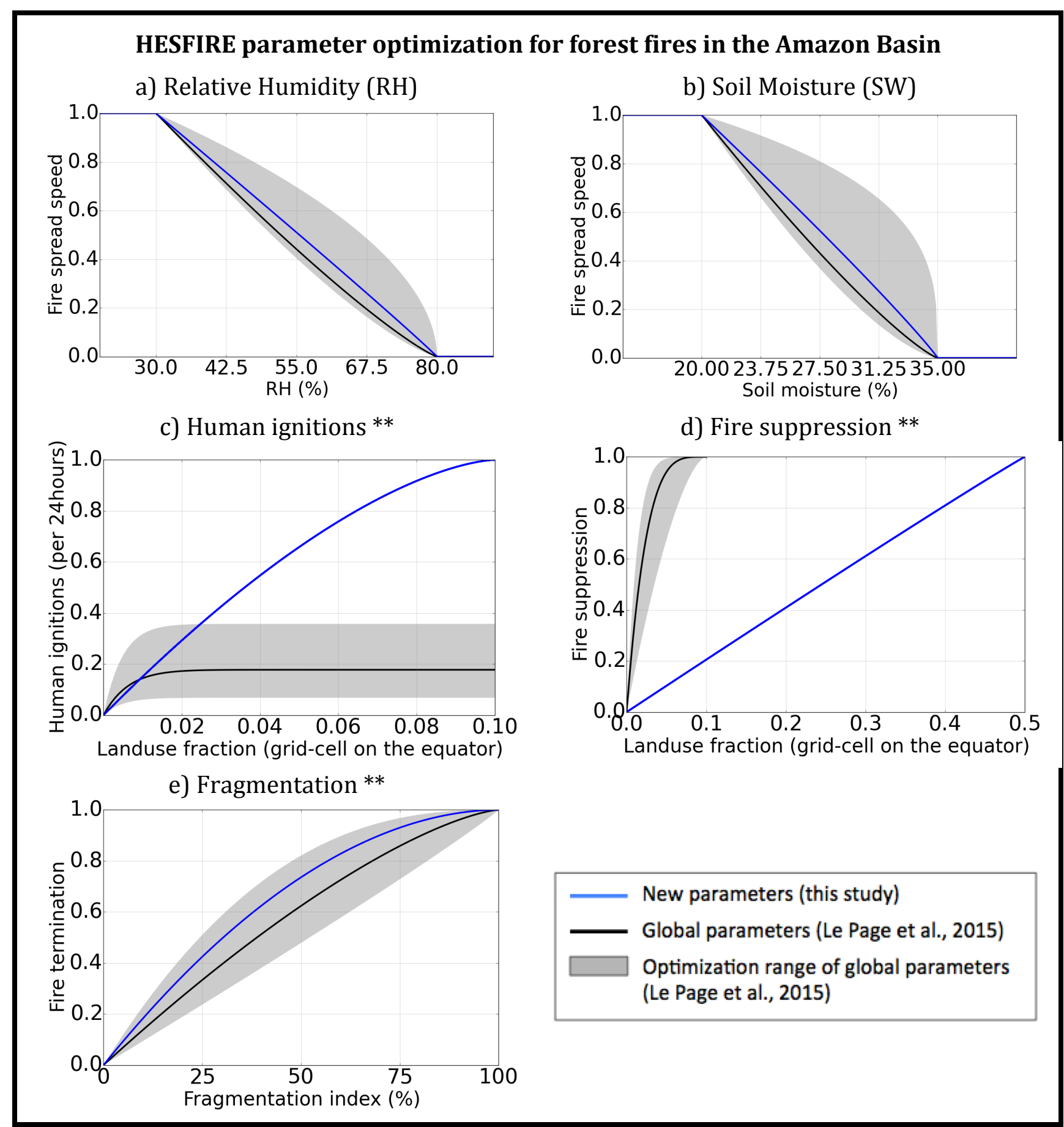

Figure S3. Re-optimization of a selection of HESFIRE parameters to maximize performance in the Amazon basin (see Methods). Global parameters and their range refer to the results of the original HESFIRE parameterization, performed at global scale (Le Page et al., 2015). ** Note that the impact of anthropogenic activities on fire ignitions, fire suppression and landscape fragmentation, when combined, are consistent with the typical bell shape relationship between human activities and fire activity (e.g. (Pechony and Shindell, 2009)). 


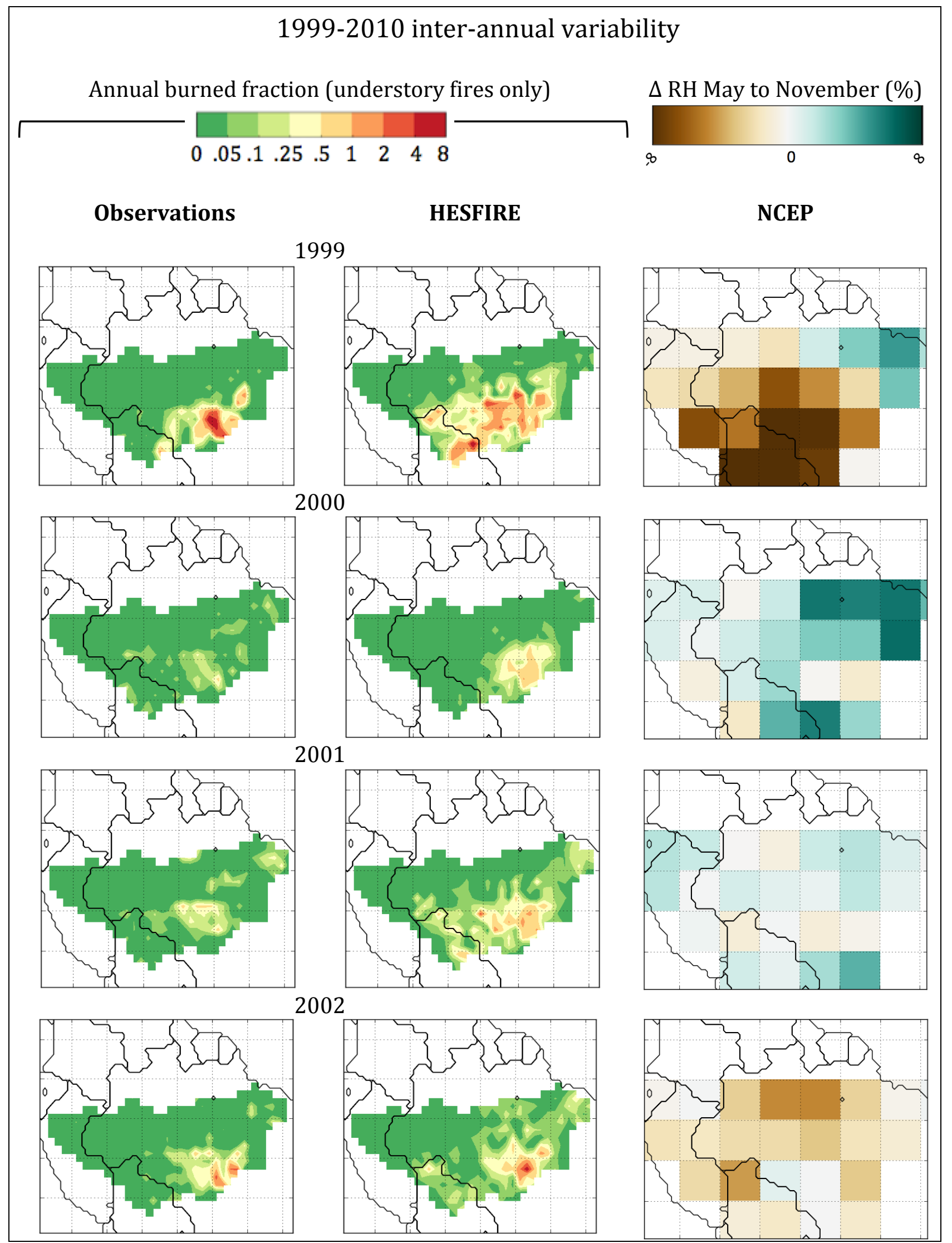




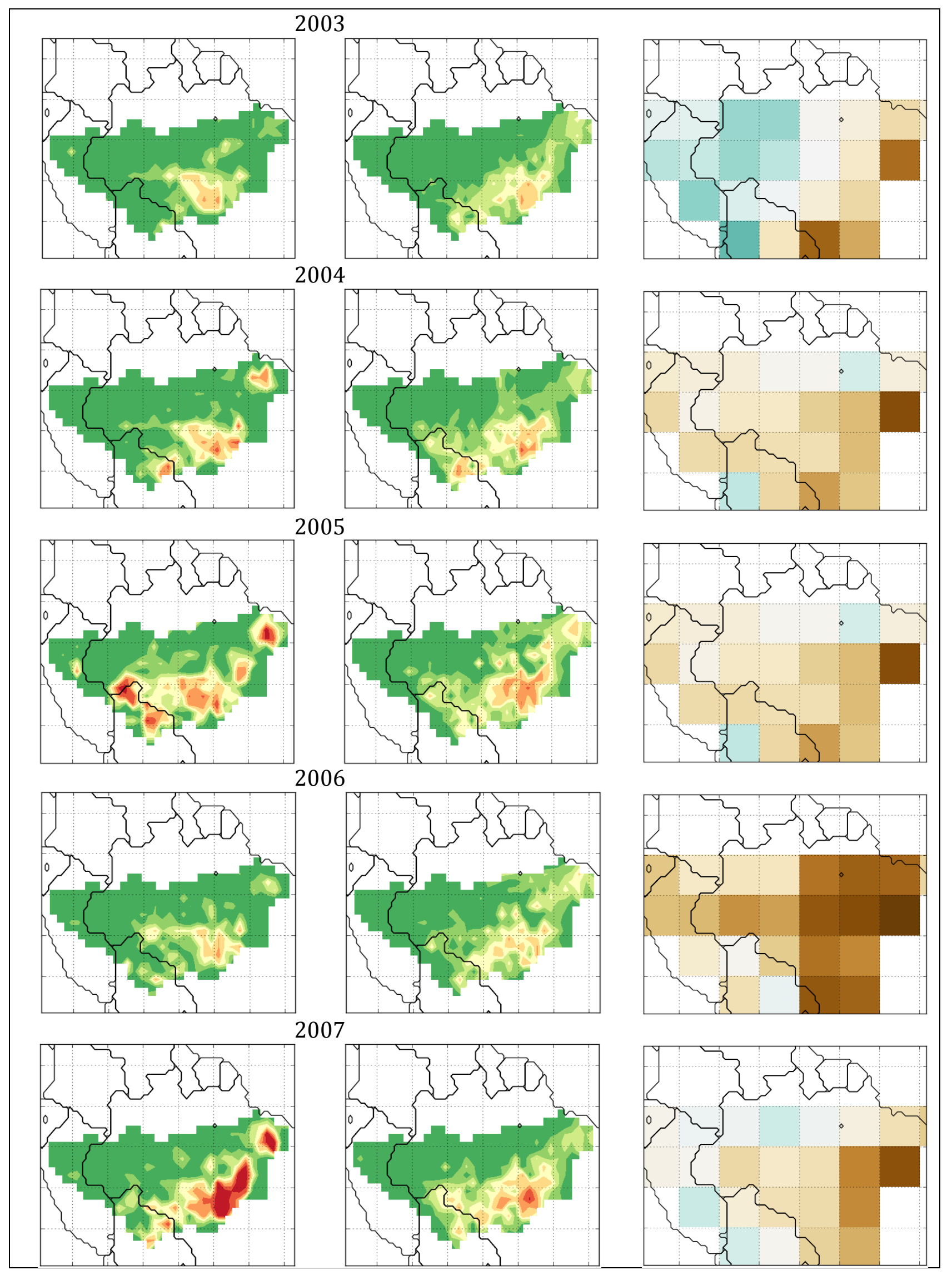




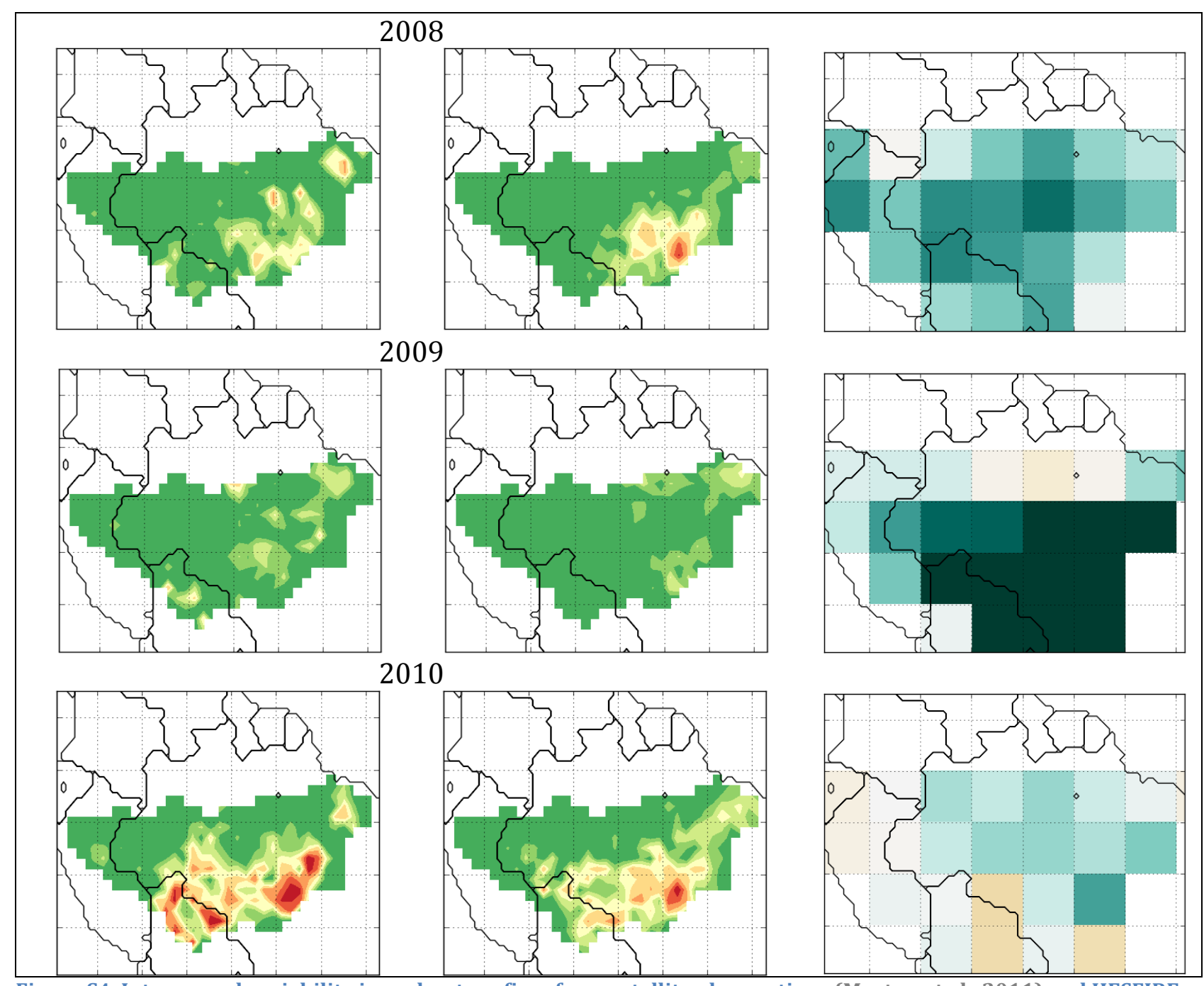

Figure S4. Interannual variability in understory fires from satellite observations (Morton et al., 2011) and HESFIRE (this study). Interannual anomalies in May-November average RH are also provided as an indicator of moisture conditions for each year. 


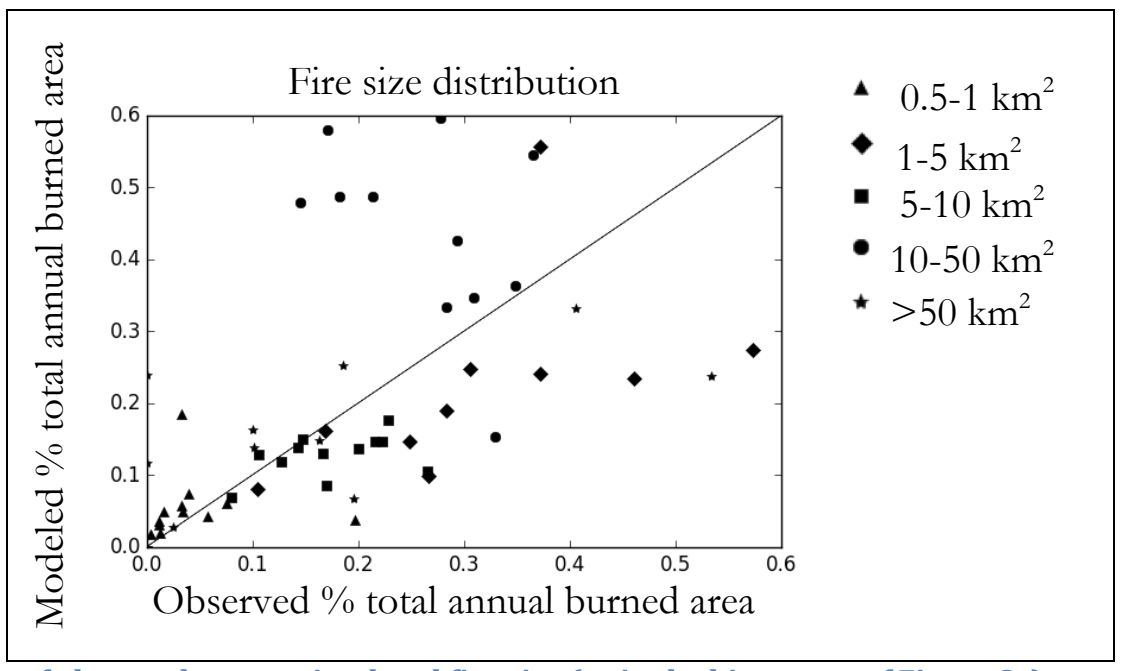

Figure S5. Scatter plot of observed versus simulated fire size (as in the histogram of Figure 2c). 


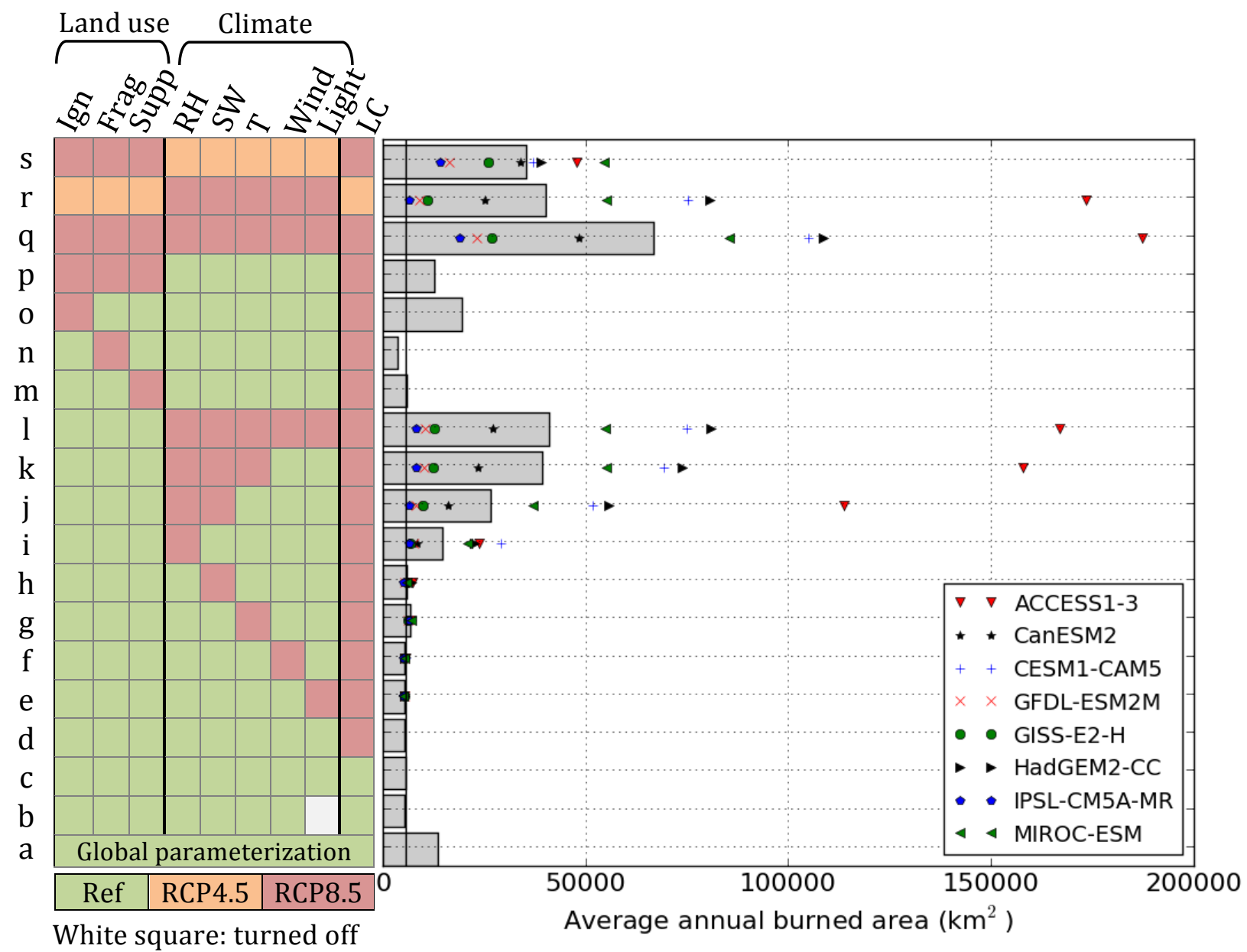

(lightning ignitions)

Figure S6. The contribution of climate and land use drivers to changes in fire activity is inferred from a factorial experiment. HESFIRE runs with different combinations of environmental change are stacked along the Y-axis (a to s). Those configurations are identified with a color code indicating which fire drivers were altered (RCP4.5 and RCP8.5) or kept unchanged (Reference, Ref). Bars represent the median value of the average burned area among 8 runs driven by different climate models. Markers indicate the value of each individual model run. Drivers abbreviations: Ign = land use ignitions; Frag = fragmentation; Supp = suppression; $\mathrm{RH}$ = relative humidity; $\mathrm{SW}$ = soil moisture; $\mathrm{T}=$ temperature; Wind = wind; Light=lightning strike ignitions; LC=land cover.

These results suggests that the parameterization of the model is consistent with our knowledge of fire dynamics in the Amazon. In particular, air and soil moisture conditions are found to be the dominant climate drivers of understory fires (Morton et al., 2013; Setzer and Sismanoglu, n.d.), followed by temperatures, but only when combined with moisture deficits (run g,k). Wind speed (run $f$ ) and lightning ignitions (run b,e, (Balch et al., 2015)) have little influence on modelled fire activity. Among anthropogenic drivers, fire ignitions are clearly dominant (run o), while suppression efforts exert little influence (run m), consistent with the challenge of deploying fire-fighting capabilities in remote regions of the Amazon (Sorrensen, 2009). 


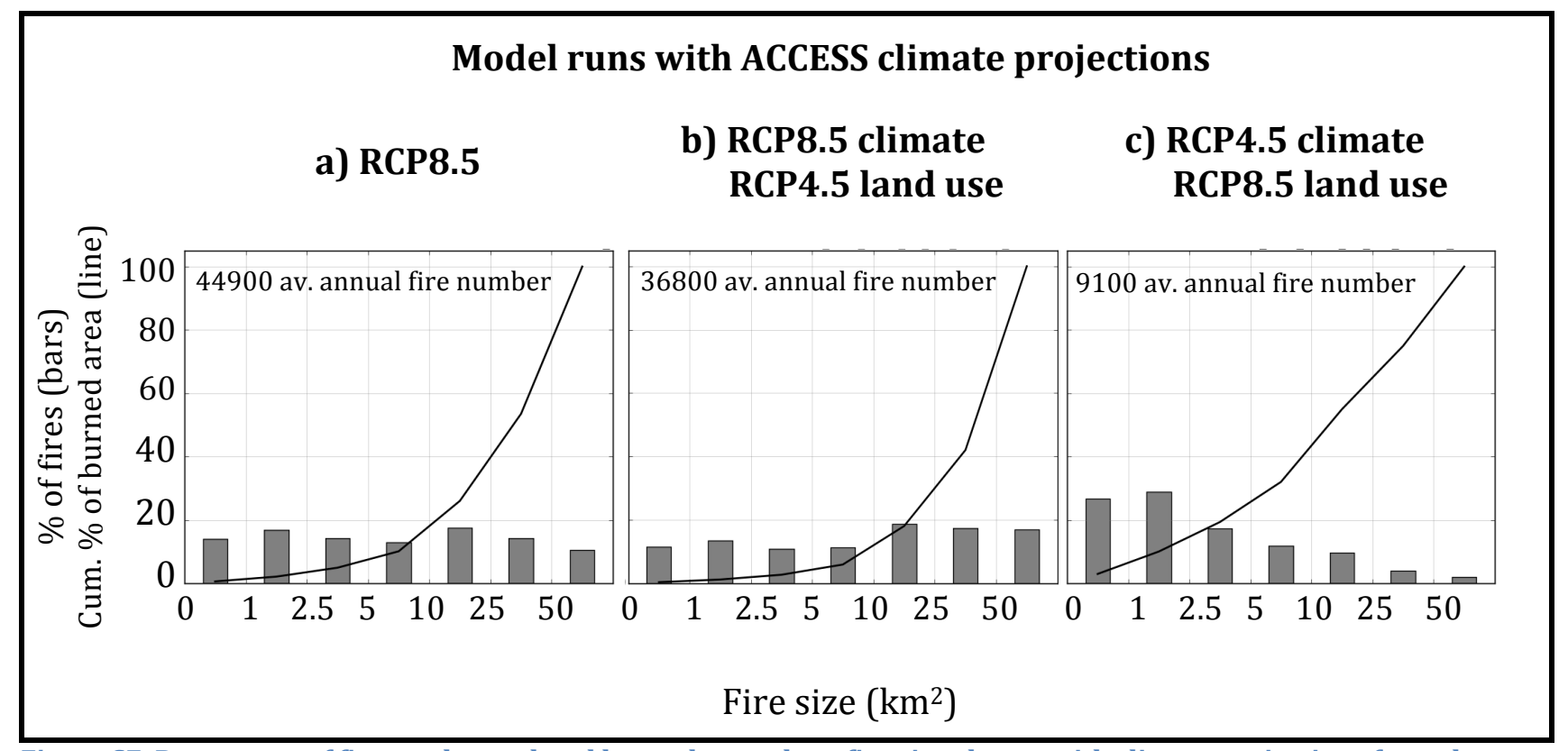

Figure S7. Percentage of fires and cumulated burned area along fire size classes with climate projections from the ACCESS model under 3 mitigation scenarios. 


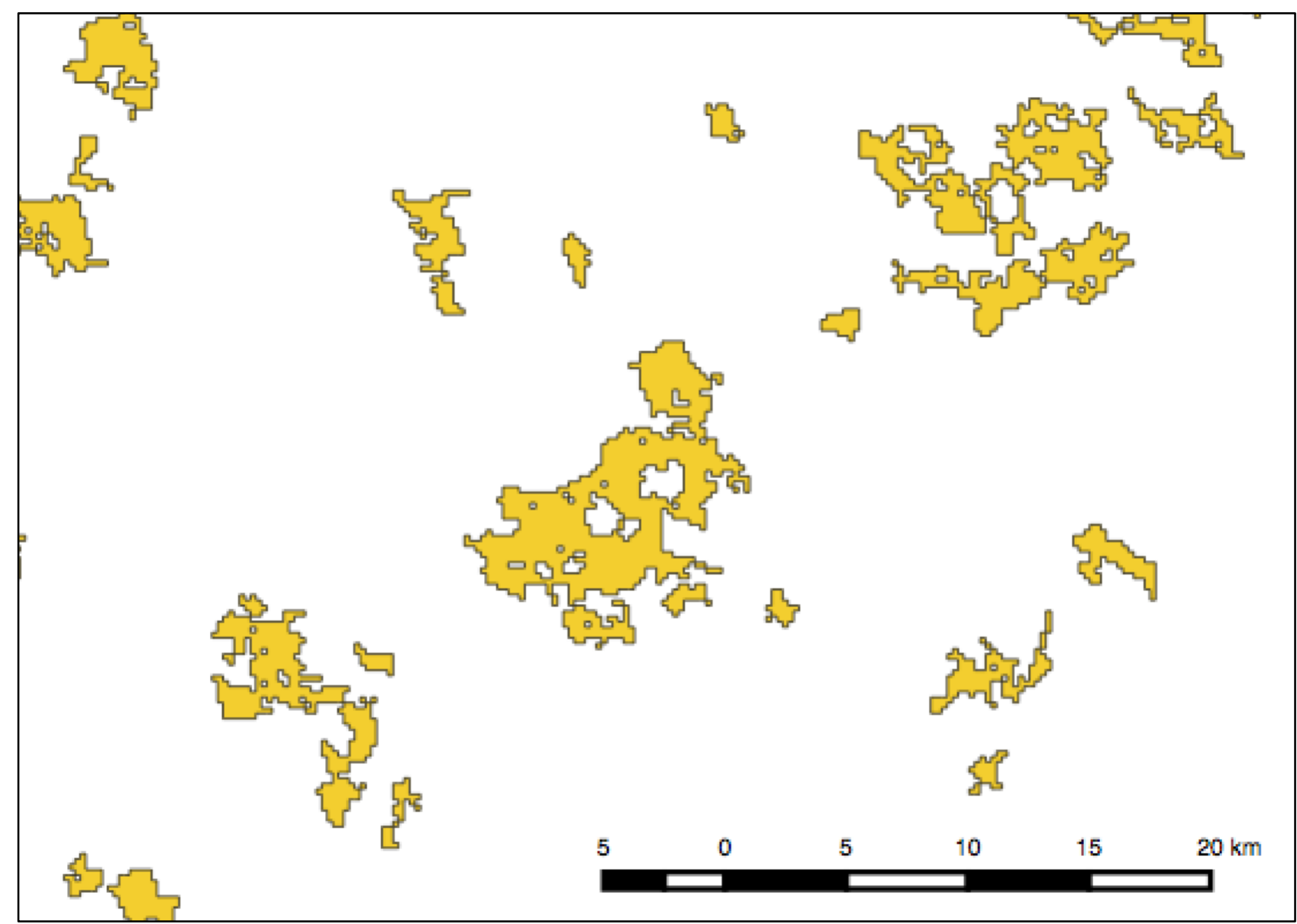

Figure S8. Typical shape of understory fires in the Amazon as detected by the Burn Damage and Recovery algorithm. 


\section{References}

Balch, J. K., Brando, P. M., Nepstad, D. C., Coe, M. T., Silvério, D., Massad, T. J., Davidson, E. A., Lefebvre, P., Oliveira-Santos, C., Rocha, W., Cury, R. T. S., Parsons, A. and Carvalho, K. S.: The Susceptibility of Southeastern Amazon Forests to Fire: Insights from a Large-Scale Burn Experiment, BioScience, 65(9), 893-905, doi:10.1093/biosci/biv106, 2015.

Le Page, Y., Morton, D., Bond-Lamberty, B., Pereira, J. and Hurtt, G.: HESFIRE: a global fire model to explore the role of anthropogenic and weather drivers, Biogeosciences, 12(3), 887-903, 2015.

Morton, D. C., DeFries, R. S., Nagol, J., Souza, C. M., Kasischke, E. S., Hurtt, G. C. and Dubayah, R.: Mapping canopy damage from understory fires in Amazon forests using annual time series of Landsat and MODIS data, Remote Sens. Environ., 115(7), 1706-1720, 2011.

Morton, D. C., Le Page, Y., DeFries, R., Collatz, G. J. and Hurtt, G. C.: Understorey fire frequency and the fate of burned forests in southern Amazonia, Philos. Trans. R. Soc. B Biol. Sci., 368(1619) [online] Available from:

http://rstb.royalsocietypublishing.org/content/368/1619/20120163.short (Accessed 7 October 2013), 2013.

Pechony, O. and Shindell, D. T.: Fire parameterization on a global scale, J. Geophys. Res. Atmospheres, 114(D16) [online] Available from: http://onlinelibrary.wiley.com/doi/10.1029/2009JD011927/full (Accessed 17 October 2016), 2009.

Setzer, A. and Sismanoglu, R.: Risco de Fogo: Metodologia do Cálculo-Descrição sucinta da Versão 9, INPE. [online] Available from:

http://queimadas.cptec.inpe.br/ rqueimadas/documentos/RiscoFogo_Sucinto. pdf (Accessed 24 June 2016), n.d.

Sorrensen, C.: Potential hazards of land policy: Conservation, rural development and fire use in the Brazilian Amazon, Land Use Policy, 26(3), 782-791, 2009.

van der Werf, G. R., Randerson, J. T., Giglio, L., Collatz, G., Mu, M., Kasibhatla, P. S., Morton, D. C., DeFries, R., Jin, Y. and van Leeuwen, T. T.: Global fire emissions and the contribution of deforestation, savanna, forest, agricultural, and peat fires (1997-2009), Atmos Chem Phys, 10(23), 11707-11735, 2010. 